\title{
Regio- and Diastereoselective 1,3-Dipolar Cycloaddition between Perfluoro-2- methyl-2-pentene and Nitrones: A Facile Approach to Partially-Fluorinated Isoxazolidines
}

\author{
Mi-Eun Moon, Joo Yeon Park, Eun-Ha Jeong, Vaishali Vajpayee, Hyunuk Kim, ${ }^{\dagger}$ and Ki-Whan Chi* \\ Department of Chemistry, University of Ulsan, Ulsan 680-749, Korea. E-mail: kwchi@ulsan.ac.kr \\ ${ }^{\dagger}$ Department of Chemistry, POSTECH, Pohang 690-784, Korea \\ Received June 23, 2009, Accepted April 14, 2010
}

\begin{abstract}
Regio- and diastereoselective 1,3-dipolar cycloaddition reactions of nitrones $\{(Z)$ - $\alpha$-phenyl- $N$-methylnitrone (1a) and (Z)- $\alpha$-propyl- $N$-butylnitrone (1b) $\}$ with electron-deficient perfluoro-2-methyl-2-pentene (2) lead to novel isoxazolidines \{5-fluoro-5-pentafluoroethyl-4,4-bis-trifluoromethyl-2-methyl-3-phenyl-isoxazolidine (3a) and 2-butyl-5-fluoro-5pentafluoroethyl-4,4-bis-trifluoromethyl-3-propyl-isoxazolidines (3b) respectively\} as major constituents. These derivatives were characterized by IR, ${ }^{1} \mathrm{H}$ and ${ }^{19} \mathrm{~F}$ NMR, GC-MS and NOE measurements, and the absolute structure of $\mathbf{3 a}$ was confirmed by X-ray crystallography.
\end{abstract}

Key Words: Perfluorinated olefin, 1,3-Dipolar cycloaddition, Isoxazolidine derivatives

\section{Introduction}

There has been an ever increasing quest for natural products containing the isoxazolidine moiety due to their vast applications as biologically active substances, e.g., plant growth regulators, ${ }^{1,2}$ antiviral, and anticancer compounds. ${ }^{3-5}$ The 1,3-dipolar cycloaddition reaction is one of the best known methods to afford 5-membered heterocyclic derivatives due to its direct, regiospecific, and stereo-controlled approach to highly-functionalized, cyclic systems. ${ }^{6,7}$

Isoxazolidines, primarily arising by the interaction of nitrones and olefins, are interesting intermediates for accessing amino alcohols, amino acids, and alkaloids. ${ }^{8-10}$ The presence of a perfluoroalkyl group (C-F group) due to a low polarizability and high lipophilicity induces a relative metabolic stability and improves the bioavailability of the modified heterocycles compared to its hydrocarbon analogues. ${ }^{11,12}$

A vast amount of literature has been published on the use of Lewis acid catalysts ${ }^{13-15}$ and ionic liquids ${ }^{16,17}$ in cycloaddition reactions to control the regio-, diastereo- and enantioselectivity of the products. The reaction mechanism can be rationalized in terms of a dominant LUMO-HOMO alkene interaction. Only a few reports are available concerning the cycloaddition reaction of electron-rich ${ }^{18}$ or electron-deficient alkenes ${ }^{19}$ with nitrones catalyzed by a chiral Lewis acid catalyst.

In this manuscript, we wish to report an efficient method applicable to the synthesis of partially-fluorinated isoxazolidines without using an external catalyst. This reaction between electron-rich nitrones and an electron-deficient olefin displays regioand diastereoselectivity leading to partially-fluorinated isoxazolidines (Scheme 1). The regioselectivity of the reaction can be understood as a Type I cycloaddition reaction dominated by a $\mathrm{HOMO}_{\text {nitrone }}(\mathbf{1} \mathbf{a}$ and $\mathbf{1 b})$ and $\mathrm{LUMO}_{\text {olefin }}(\mathbf{2})$ interaction. ${ }^{20-21}$

The syntheses of nitrones, $(Z)$ - $\alpha$-phenyl- $N$-methylnitrone (1a) $)^{22}$ and $(Z)$ - $\alpha$-propyl- $N$-butylnitrone $(\mathbf{1 b})^{23}$ were accomplished by literature procedures.

The primary focus of our work was the optimization of syn- thesis protocols for the isoxazolidines. The results are summarized in Table 1.

We observed that increasing the molar ratio of olefin with respect to nitrone improved the yield of the desired products, 3a and 4a, as two constitutional isomers in a 3:1 ratio. The ratio of isomeric products was not affected by changing the molar ratio of reactants.

The electron-deficient nature and high substitution of the perfluoro-2-methyl-2-pentene olefin make it a well tuned cycloaddition reaction partner with nitrones resulting in high yields of

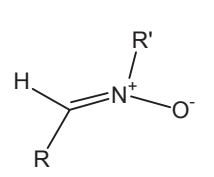

1

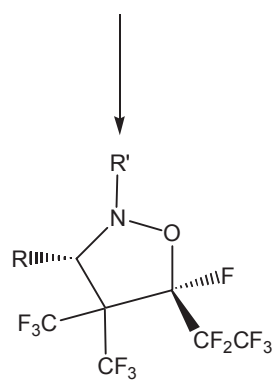

3

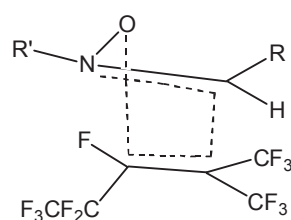<smiles>CC(C)(C(F)=C(C(F)(F)F)C(F)(F)C(F)(F)F)C(F)(F)F</smiles><smiles>[R]C1N([R])C2(C(F)(F)F)CC1(C(F)(F)F)C2[R]</smiles>

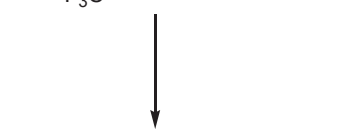<smiles>[R][C@H]1N([R])OC(C(F)(F)F)(C(F)(F)F)[C@@]1(F)C(F)(F)F</smiles>

4
Scheme 1. 1,3-Dipolar reaction of nitrones and perfluoro-2-methyl2-pentene. 
Table 1. Optimization studies for the cycloaddition reaction.

\begin{tabular}{ccc}
\hline $\begin{array}{c}\text { Solvent } \\
\text { (Reaction temperature) }\end{array}$ & $\begin{array}{c}\text { Molar ratio of } \\
\text { reactants (1a:2) }\end{array}$ & $\begin{array}{c}\text { Yield (\%) of 3a } \\
\text { and 4a }\end{array}$ \\
\hline Toluene $\left(80^{\circ} \mathrm{C}\right)$ & $1.0: 1.2$ & 55 \\
$1.0: 2.0$ & 67 \\
\hline Toluene/perfluoro-hexane & $1.0: 1.2$ & 20 \\
$\left(60^{\circ} \mathrm{C}\right)$ & $1.0: 2.6$ & 83 \\
& $1.0: 5.0$ & 90 \\
\hline & $1.0: 1.2$ & 53 \\
\hline
\end{tabular}

Table 2. Regioselectivity of the 1,3-dipolar cycloaddition reaction of nitrones

\begin{tabular}{ccccccc}
\hline \multicolumn{2}{c}{ No. Nitrone Olefin } & $\begin{array}{c}\text { Molar ratio } \\
\text { of } \mathbf{1 : 2}\end{array}$ & Products & $\begin{array}{c}\text { Yield (\%) } \\
\text { of } \mathbf{3} \text { and } \mathbf{4}\end{array}$ & $\begin{array}{c}\text { Product } \\
\text { ratio of } \mathbf{3 : 4 ^ { c }}\end{array}$ \\
\hline 1 & $\mathbf{1 a}$ & $\mathbf{2}$ & $1: 2.0$ & $\mathbf{3 a}+\mathbf{4 a}$ & 87 & $3: 1$ \\
2 & $\mathbf{1 b}$ & $\mathbf{2}$ & $1: 2.0$ & $\mathbf{3 b}+\mathbf{4 b}$ & 40 & $2: 1$
\end{tabular}

${ }^{a}$ Reaction Conditions: the mixture was stirred in THF for $3 \mathrm{~h}$ at $60{ }^{\circ} \mathrm{C}$, ${ }^{b}$ Yield: isolated yields, ${ }^{c}$ isomer ratios were determined by NMR spectroscopy.

partially-fluorinated isoxazolidines. With the two nitrones investigated, different ratios of an inseparable mixture of isoxazolidine constitutional isomers were produced (Table 2).

The regio- and distereoselectivity of the reaction were established with the support of ${ }^{1} \mathrm{H}$ and ${ }^{19} \mathrm{~F}$ NMR spectral data. For the sake of clarity, spectral details of the product mixture of $\mathbf{3} \mathbf{a}$ and 4a are discussed below.

In the ${ }^{1} \mathrm{H}$ NMR spectra, the characteristic signal for the $\mathrm{C}-\mathrm{H}$ proton observed at $\delta 4.27$ and $\delta 4.86 \mathrm{ppm}$ in a $3: 1$ intensity ratio suggests the presence of two types of $\mathrm{C}-\mathrm{H}$ protons. The signal at $\delta 4.27$ is consistent with the major product $\mathbf{3} \mathbf{a}$ in which the fluorine atom is far from the $\mathrm{C}-\mathrm{H}$ proton leading to an upfield shift as compared to the minor product 4a in which the fluorine is directly attached to the same side of C-H leading to a downfield shift at $\delta 4.86 \mathrm{ppm}$. In the ${ }^{19} \mathrm{~F}$ NMR, the two signals as multiplets for $\mathrm{C}-\mathrm{F}$ at $\delta-108.49 \mathrm{ppm}$ and $\delta-95.69 \mathrm{ppm}$ in a 3:1 intensity ratio is in agreement with the presence of two isomers. Furthermore, two signals were found for the phenyl and methyl groups in the ${ }^{1} \mathrm{H}$ NMR spectra, and in the ${ }^{19} \mathrm{~F}$ NMR spectra, two signals were evident for the $\mathrm{CF}_{3}, \mathrm{CF}_{2}$, and $\mathrm{CF}_{2} \mathrm{CF}_{3}$ groups in 3:1 intensity ratios, validating the presence of only two constitutional isomers.

To confirm the structures of these isomers, we opted to perform NOE measurement studies (Fig. 1). Irradiation of the proton at $\delta 4.27$ ppm (3a) was observed to enhance the ${ }^{19} \mathrm{~F}$ NMR signal for the fluorine of the $\mathrm{CF}_{3}$ at $\delta-63.65 \mathrm{ppm}$, and no enrichment of the $\mathrm{CF}_{3}$ fluorine signal on irradiation of the proton at $\delta 4.86 \mathrm{ppm}$ (4a) verified the structures and presence of two isomers in the mixture.

The absolute configuration of 5-fluoro-5-pentafluoroethyl4,4-bis-trifluoromethyl-2-methyl-3-phenyl-isoxazolidine (3a) was proven by an X-ray structure (Fig. 2). The crystal structure of 3a corroborates conclusions based on the NMR and NOE

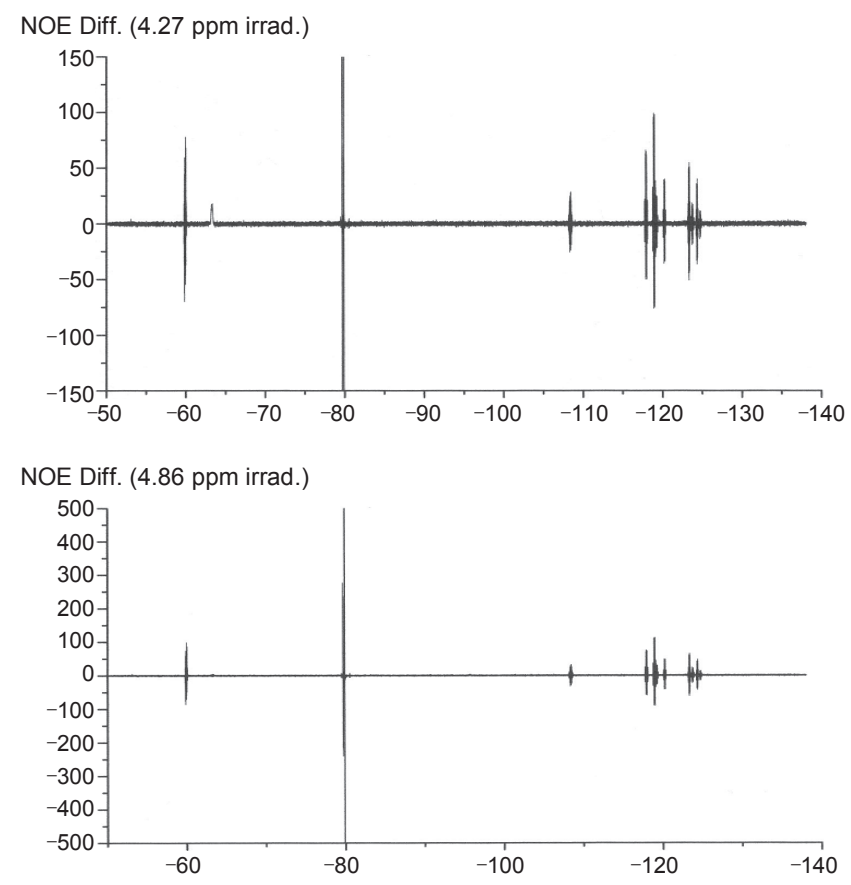

Figure 1. NOE spectral data for isoxazolidine derivatives $\mathbf{3 a}$ and $\mathbf{4 a}$.

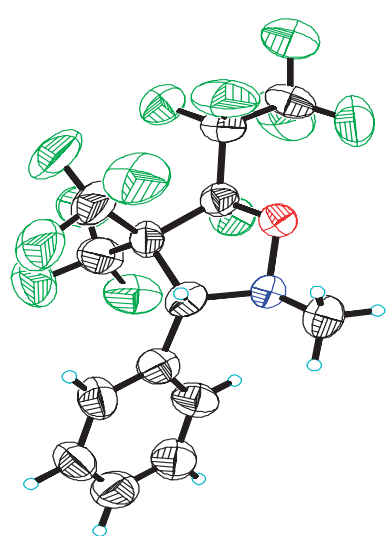

Figure 2. X-ray crystal structure of 5-fluoro-5-pentafluoroethyl-4,4bis-trifluoromethyl-2-methyl-3-phenyl-isoxazolidine (3a) with 50\% ellipsoid.

data.

Finally, while the possible formation of other isoxazolidine diastereomers can not be ruled out, it is reasonable to postulate that steric factors played an important role in controlling the diastereoselectivity of the isoxazolidines produced and can help prevent the formation of other isoxazolidine isomers during the course of the reaction.

In conclusion, we have synthesized new, partially-fluorinated isoxazolidines in good to moderate yields by an operationally simple 1,3-dipolar cycloaddition reaction of nitrones with a fluorinated olefin. The regio- and distereoselectivity of the reaction were explained by the possible electronic interactions and/or steric hindrance of the reactants during their approach in the transition state. 


\section{Experimental Details}

General methods. The ${ }^{1} \mathrm{H}$ and ${ }^{19} \mathrm{~F}$ NMR spectra were recorded in $\mathrm{CDCl}_{3}$ on a Varian Unity Inova $500 \mathrm{FT}-\mathrm{NMR}$. Mass spectra were performed on a Varian Saturn 2200 GC/MS by chemical ionization, and IR spectra ( $\mathrm{KBr})$ were recorded on a Mattson5000 (UNICAM). Melting points were carried out on a MELTEMP II instrument.

Materials. (Z)- $\alpha$-Phenyl- $N$-methylnitrone (1a) ${ }^{22}$ and $(Z)-\alpha-$ propyl- $N$-butylnitrone $(\mathbf{1 b})^{23}$ were synthesized by the reported methods. Commercial grade perfluoro-2-methyl-2-pentene (2) was used without purification.

General procedure for the synthesis of isoxazolidines. A solution of nitrone $1 \mathbf{a}(106 \mathrm{mg}, 0.787 \mathrm{mmol})$ and perfluoro-2-methyl-2-pentene $(624 \mathrm{mg}, 2.08 \mathrm{mmol})$ in THF $(10 \mathrm{~mL})$ was added to a sealed tube containing a magnetic stirring bar. The reaction mixture was vigorously stirred at $60{ }^{\circ} \mathrm{C}$ for $3 \mathrm{~h}$ in an oil bath. After completion of the reaction (TLC), the solvent was distilled off, and traces of solvent were removed on a rotary evaporator. The crude product was then subjected to column chromatography (eluent $100 \%$ Hexane) to yield the mixture of products $\mathbf{3} \mathbf{a}$ and 4a as colorless, transparent crystals $\left(279 \mathrm{mg}, 87 \%\right.$, mp $\left.46.5^{\circ} \mathrm{C}\right)$.

5-Fluoro-5-pentafluoroethyl-4,4-bis-trifluoromethyl-2-methyl-3-phenyl-isoxazolidine (3a) and 4-fluoro-4-pentafluoroethyl-5,5-bis-trifluoromethyl-2-methyl-3-phenyl-isoxazolidine (4a): Colorless transparent solid, Yield: $87 \%$, mp $46.5^{\circ} \mathrm{C}$, IR $\left(\mathrm{cm}^{-1}\right)$ : 3090, 2923, 1975, 1459, 1228, 1142, 1034, 975, 940, $889,849,741,701,625,542,473$. MS $m / z$ (rel. intensity): 436 $\left(\mathrm{M}^{+}+1,100\right), 357$ (2.5), 319 (3.5), 223 (20). 3a: ${ }^{1} \mathrm{H}$ NMR (500 $\left.\mathrm{MHz}, \mathrm{CDCl}_{3}\right) \delta 2.88\left(\mathrm{~s},-\mathrm{CH}_{3}, 3 \mathrm{H}\right), 4.27(\mathrm{~d}, \mathrm{Ar}-\mathrm{CH}, 1 \mathrm{H}), 7.43(\mathrm{~m}$, $\mathrm{Ar}-\mathrm{H}, 5 \mathrm{H}) ;{ }^{19} \mathrm{~F}$ NMR $\left(282.2 \mathrm{MHz}, \mathrm{CDCl}_{3}\right) \delta-124.45\left(\mathrm{~m},-\mathrm{CF}_{2}-\right.$ $\left.\mathrm{CF}_{3}, 2 \mathrm{~F}\right),-108.49(\mathrm{~m},-\mathrm{CF}, 1 \mathrm{~F}),-80.25\left(\mathrm{~d}, J=28.2 \mathrm{~Hz},-\mathrm{CF}_{2} \overline{\mathrm{CF}_{3}}\right.$, $3 \mathrm{~F}),-63.65\left(\mathrm{~m},-\mathrm{CF}_{3}, 3 \mathrm{~F}\right),-60.35\left(\mathrm{~m},-\mathrm{CF}_{3}, 3 \mathrm{~F}\right) .4 \mathrm{a}:{ }^{1} \mathrm{H} \mathrm{NMR}$ $\left(500 \mathrm{MHz}, \mathrm{CDCl}_{3}\right) \delta 2.97\left(\mathrm{~s},-\mathrm{CH}_{3}, 3 \mathrm{H}\right), 4.86(\mathrm{~m}, \mathrm{Ar}-\mathrm{CH}, 1 \mathrm{H})$, 7.68 (s, Ar-H, 5H); ${ }^{19} \mathrm{~F}$ NMR (282.2 MHz, $\left.\mathrm{CDCl}_{3}\right) \delta-119.51$ (dq, $\left.J=15.51,39.95 \mathrm{~Hz},-\mathrm{CF}_{2} \mathrm{CF}_{3}, 2 \mathrm{~F}\right),-95.69$ (m, -CF, 1H), $-80.05\left(\mathrm{~d}, J=23.97 \mathrm{~Hz},-\overline{\mathrm{CF}}_{2} \mathrm{CF}_{3}, 3 \mathrm{~F}\right),-60.35\left(\mathrm{~m},-\mathrm{CF}_{3}, 3 \mathrm{~F}\right)$, $-59.25\left(\mathrm{~s},-\mathrm{CF}_{3}, 3 \mathrm{~F}\right)$.

2-Butyl-5-fluoro-5-pentafluoroethyl-4,4-bis-trifluoromethyl3-propyl-isoxazolidine (3b) and 2-butyl-4-fluoro-4-pentafluoroethyl-5,5-bis-trifluoromethyl-3-propyl-isoxazolidine (4b): Colorless transparent liquid, Yield: 40\%. IR ( $\left.\mathrm{cm}^{-1}\right)$ : 2966, 2940, 2881, 1469, 1330, 1274, 1211, 1130, 1045, 1025, 970, 943, 875, 850, 742. MS $m / z$ (rel. intensity): $444\left(\mathrm{M}^{+}+1,100\right), 425$ (29), 144 (7.5). 3b: ${ }^{1} \mathrm{HNMR}\left(500 \mathrm{MHz}, \mathrm{CDCl}_{3}\right) \delta 0.92\left(\mathrm{~m},-\mathrm{CH}_{2} \mathrm{CH}_{2} \mathrm{CH}_{3}\right.$, $3 \mathrm{H}), 0.99\left(\mathrm{~m},-\mathrm{CH}_{2} \mathrm{CH}_{2} \mathrm{CH}_{2} \mathrm{CH}_{3}, 3 \mathrm{H}\right), 1.39-1.40\left(\mathrm{~m},-\mathrm{CH}_{2} \overline{\mathrm{CH}}_{2}-\right.$ $\left.\mathrm{CH}_{3}, 4 \mathrm{H}\right), 1.64-1.65\left(\mathrm{~m},-\mathrm{CH}_{2} \mathrm{CH}_{2} \mathrm{CH}_{2} \mathrm{CH}_{3}, 4 \mathrm{H}\right), 2.82$ (m, $-\mathrm{CH}_{2}-$ $\left.\mathrm{CH}_{2} \mathrm{CH}_{2} \mathrm{CH}_{3}, 2 \mathrm{H}\right), 3.11$ (m, $\left.-\overline{\mathrm{CH}}, 1 \mathrm{H}\right) ;{ }^{19} \mathrm{~F} \mathrm{NMR}(282.2 \mathrm{MHz}$, $\left.\mathrm{CDCl}_{3}\right) \delta-60.50$ (br.s, $\left.-\mathrm{CCF}_{3}, 3 \mathrm{~F}\right),-61.81\left(\mathrm{~m},-\mathrm{CCF}_{3}, 3 \mathrm{~F}\right),-80.42$ $\left(\mathrm{d}, J=15.6 \mathrm{~Hz},-\mathrm{CF}_{2} \mathrm{CF}_{3}, 3 \mathrm{~F}\right),-80.72\left(\mathrm{~d}, J=18.0 \mathrm{~Hz},-\mathrm{CF}_{2} \mathrm{CF}_{3}\right.$, $3 \mathrm{~F}),-108.18$ (br.s, $-\mathrm{CF}, 1 \mathrm{~F}),-118.94$ (dq, $J=34.6,8.3 \mathrm{~Hz},-\overline{\mathrm{CF}}_{2}-$ $\left.\mathrm{CF}_{3}, 2 \mathrm{~F}\right),-120.25$ (dq, $\left.J=28.2,9.3 \mathrm{~Hz},-\mathrm{CF}_{2} \mathrm{CF}_{3}, 2 \mathrm{~F}\right) .4 \mathbf{b :}{ }^{1} \mathrm{H}$ $\operatorname{NMR}\left(500 \mathrm{MHz}, \mathrm{CDCl}_{3}\right) \delta$ 0.93-0.97 (m, $\left.-\mathrm{CH}_{2} \mathrm{CH}_{2} \mathrm{CH}_{3}, 3 \mathrm{H}\right)$, $1.00\left(\mathrm{~m},-\mathrm{CH}_{2} \mathrm{CH}_{2} \mathrm{CH}_{2} \mathrm{CH}_{3}, 3 \mathrm{H}\right), 1.42-1.55$ (m, $-\mathrm{CH}_{2} \overline{\mathrm{CH}}_{2} \mathrm{CH}_{3}$, $4 \mathrm{H}), 1.94-2.01\left(\mathrm{~m},-\mathrm{CH}_{2} \mathrm{CH}_{2} \mathrm{CH}_{2} \mathrm{CH}_{3}, 4 \mathrm{H}\right), 3.02 \overline{\left(\mathrm{m},-\mathrm{CH}_{2}\right.} \mathrm{CH}_{2}-$ $\left.\mathrm{CH}_{2} \mathrm{CH}_{3}, 2 \mathrm{H}\right), 3.15(\mathrm{t},-\mathrm{CH}, 1 \mathrm{H}) ;{ }^{19} \mathrm{~F} \mathrm{NMR}\left(282.2 \mathrm{MHz}, \mathrm{CDCl}_{3}\right)$ $\delta-64.78$ (br.s, $-\mathrm{CCF}_{3}, 3 \mathrm{~F}$ ), -60.52 (br.s, $\left.-\mathrm{CCF}_{3}, 3 \mathrm{~F}\right),-100.89$ (br.s, $-\mathrm{CF}, 1 \mathrm{~F}),-118.33$ (dq, $J=34.1,7.8 \mathrm{~Hz},-\mathrm{CF}_{2} \mathrm{CF}_{3}, 2 \mathrm{~F}$ ),
-119.65 (dq, $\left.J=28.2,8.8 \mathrm{~Hz},-\underline{\mathrm{CF}_{2}} \mathrm{CF}_{3}, 2 \mathrm{~F}\right)$.

Acknowledgments. We gratefully acknowledge the WCU program (R33-2008-000-10003-0) and Priority Research Centers Program (2009-0093818) of the Korean Ministry of Education, Science and Technology for the support of this work. X-ray diffraction experiments using synchrotron radiation were performed at the Pohang Accelerator Laboratory supported by MOST and POSTECH.

Supporting Information Available. Crystallographic data of the derivative 3a has been deposited with Cambridge Crystallographic Data Centre (Deposition No. CCDC 723303). This data can be obtained free of charge via http://www.ccdc.cam.uk/perl/ catreg.cgi (or from the CCDC, 12 Union Road, Cambridge CB2 1EZ, UK; fax: +44 1223 336033; email: deposit@ccdc. cam.ac.uk).

\section{References}

1. Purser, S.; Moore, P. R.; Swallow, S.; Gouverneur, V. Chem. Soc. Rev. 2008, 37, 320.

2. Ochiai, M.; Obayashi, M.; Morita, K. Tetrahedron 1967, 23, 2641.

3. (a) Moldavsky, D. D.; Furin, G. G. Zh. Obshch. Khim. 1996, 66, 1995. (b) Donadas, H. A.; Fishwick, C. W. G.; Grigg, R.; Kilner, C. Tetrahedron 2004, 60, 3473. (c) Macchi, B.; Balestreri, E.; Mastino, A. J. Antimicrob. Chemother. 2003, 51, 1327. (d) De Clercq, E. Med. Res. Rev. 2002, 22, 531.

4. Mashella, H.; Ravikumar, K. R.; Mantelingu, K.; Rangappa, K. S. Synthesis 2001, 10, 1459.

5. (a) Iannazzo, D.; Piperno, A., Pistara, V.; Rescifina, A.; Romeo, R. Tetrahedron 2002, 58, 581. (b) Chiacchio, U.; Corsaro, A.; Gumina, G.; Rescifina, A.; Iannazzo, D.; Piperno, A.; Romeo, G.; Romeo, R. J. Org. Chem. 1999, 64, 9321. (c) Chiacchio, U.; Corsaro, A.; Iannazzo, D.; Piperno, A.; Pistara, V.; Rescifina, A.; Romeo, R.; Sindona, G.; Romeo, G. Tetrahedron: Asymmetry 2003, 14, 2717.

6. Singh, R.; Bhella, S. S.; Sexana, A. K.; Shanmigavel, M.; Faruk, A.; Ishar, M. P. S. Tetrahedron 2007, 63, 2283.

7. Frederickson, M. Tetrahedron 1997, 53, 403.

8. (a) Torssell, K. B. G. Nitrile Oxides, Nitrones and Nitronates in Organic Synthesis; VCH: New York, 1988. (b) Gothelf, K. V.; Jørgensen, K. A. Chem. Rev. 1998, 98, 863.

9. Seerden, J. -P. G.; Boeren, M. M. M.; Scheeren, H. W. Tetrahedron 1997, 53, 11843.

10. Jakowiecki, J.; Loska, R.; Makosza, M. J. Org. Chem. 2008, 73, 5436.

11. Arnone, A.; Bernardi, R.; Blasco, F.; Cardillo, R.; Gerus, I. I.; Kukhar, V. P. Tetrahedron 1998, 54, 2809.

12. (a) Chambers, R. D. Fluorine in Organic Chemistry; Blackwell Publishing: Oxford, UK, 2004 (b) Kirsch, P. Modern Fluoroorganic Chemistry; Wiley-VCH: Weinheim, Germany, 2004.

13. Padwa, A., Pearson, W. H., Eds.; Synthetic Applications of 1,3Dipolar Cycloaddition Chemistry Toward Heterocycles and Natural Products; Wiley \& Sons: Hoboken, 2003.

14. Mita, T.; Ohtsuki, N.; Ikeno, T.; Yamada, T. Org. Lett. 2002, 4, 2457.

15. Kanemasa, S.; Tsuruoka, T.; Yamamoto, H. Tetrahedron Lett. $1995,36,5019$.

16. (a) Pàdàr, P.; Bokros, A.; Paragi, G.; Forgò, P.; Kele, Z.; Howarth, N. M.; Kovàcs, L. J. Org. Chem. 2006, 71, 8669. (b) Conti, D.; Rodriquez, M.; Sega, A.; Taddei, M. Tetrahedron Lett. 2003, 44, 5327. (c) Bortolini, O. ; De Nino, A.; Maiuolo, L.; Tocci, A.; Fantin, G.; Fogagnolo, M. Chem. Lett. 2007, 472.

17. Bortolini, O.; De Nino, A.; Maiuolo, L.; Russo, B.; Sindona, G.; 
Tocci, A. Tetrahedron Lett. 2007, 48, 7125.

18. (a) Jensen, K. B.; Hazell, R. G. ; Jørgensen, K. A. J. Org. Chem. 1999, 64, 2353. (b) Simonsen, K. B.; Bayon, P.; Hazell, R.G.; Gothelf, K. V.; Jørgensen, K. A. J. Am. Chem. Soc. 1999, 121, 3845.

19. (a) Iwasa, S.; Tsushima, S.; Shimada, T.; Nishiyama, H. Tetrahedron 2002, 58, 227. (b) Desimoni, G.; Faita, G.; Mortoni, A.; Righetti, P. Tetrahedron Lett. 1999, 40, 2001.
20. Padwa, A., Pearson, W. H., Eds.; The Chemistry of Heterocyclic Compounds; Vol. 59, Synthetic Applications of 1,3-Dipolar Cycloaddition Chemistry; Wiley: New York, 2002.

21. Gothelf, K.V.; Jørgensen, K. A. Chem. Rev. 1998, 98, 863.

22. Dickin, C. M.; Deshong, P. J. Org. Chem. 1982, 47, 2047.

23. Murahashi, S.-I.; Mitsui, H.; Shiota, T.; Tsuda, T.; Watanabe, S. J. Org. Chem. 1990, 55, 1736. 